\title{
Research on the Sedimentation of Underwater Distributary Channels in Shallow Lacustrine Delta---Case Study of B19-4 Oilfield, Bohai Bay Basin
}

\author{
Shi Changlin ${ }^{1}$, Yang Lina ${ }^{1,}$, , Tian Panpan ${ }^{1}$, Wang Xinran ${ }^{2}$ \\ ${ }^{1}$ CNOOC EnerTech - Drilling \& Production Co. Ltd., Tianjin, China \\ ${ }^{2}$ Tianjin Branch of CNOOC (China) Ltd., Tianjin, China
}

Email address:

ex_yln@cnooc.com.cn (Yang Lina)

${ }^{*}$ Corresponding author

\section{To cite this article:}

Shi Changlin, Yang Lina, Tian Panpan, Wang Xinran. Research on the Sedimentation of Underwater Distributary Channels in Shallow Lacustrine Delta---Case Study of B19-4 Oilfield, Bohai Bay Basin. International Journal of Oil, Gas and Coal Engineering. Vol. 8, No. 4, 2020, pp. 75-81. doi: 10.11648/j.ogce.20200804.11

Received: June 29, 2020; Accepted: July 21, 2020; Published: August 4, 2020

\begin{abstract}
Based on the data of core observation, grain size analysis, micro paleontology, logging and well logging, the sedimentary environment and characteristics of NmIII and NmIV oil formation in the lower Minghuazhen Formation of B19-4 Oilfield are studied, and the formation reason of narrow strip sand body in this area is explained. The characteristics of formation thickness, lithology, paleontology and sedimentary microfacies indicate that the lower Minghuazhen Formation of B19-4 Oilfield belongs to the shallow water delta deposition of continental lake basin in the background of rising to falling from base level. The sedimentary environment is characterized by gentle slope, large accommodation space, weak hydrodynamic force, far-reaching sediment source, relatively stable structure, etc. the sedimentary sand body is dominated by distributary channel deposition, with developed natural dikes, and undeveloped mouth bars and crevasse fans. Because of this sedimentary environment, the underwater distributary channel of the shallow water delta is not easy to be changed, and the sand bodies of the underwater distributary channel of the multi-stage sedimentary cycles are vertically superposed, forming the sand bodies with narrow strip distribution.
\end{abstract}

Keywords: Shallow Lacustrine Delta, Sedimentary Environment, Sand Bodies Superposition

\section{Introduction}

The Neogene Lake Basin of Bohai Bay basin developed in the lower depression stage of the basin as a whole, which was filled up by the peneplanarization during the deposition period of the Guantao Formation. The slope at the bottom of the basin is relatively gentle, and the climate is mainly subtropical. It is easy to form a broad shore shallow lake sedimentary area, and a large shallow lake delta sedimentary system at the place where the river enters the lake $[1,2]$.

B19-4 oilfield is located in the structural zone bordered by Bozhong depression, Shanan depression, Bonan uplift and Shaleitian uplift, surrounded by three major oil generating depressions, Shanan, Huanghekou and Bozhong. It is one of the main oilfields in the Bohai Sea area. The NmIII and NmIV oil formations in the lower Minghuazhen Formation of the oilfield are the main oil reservoirs [3, 4]. Because the channel sand body is in a narrow strip, previous studies have considered that the area belongs to shallow delta narrow channel deposition, and no study has been made on its genesis. This paper studies the sedimentary environment and characteristics by comprehensive utilization of seismic, logging, core, and experimental data. It is considered that the channel width of the NmIII and NmIV oil groups in this area ranges from 250 to $300 \mathrm{~m}$; the thickness of sand bodies in a single stage ranges from 2 to $9 \mathrm{~m}$; the width-to-depth ratio ranges from 28 to 150 ; and it belongs to the underwater distributary channel deposition in shallow-water delta of continental lake basin $[5,6]$. And the width depth ratio of single channel sand body belongs to the category of normal River, not narrow channel. At the same time, through the analysis of sedimentary characteristics and the genesis of 
narrow strip sand body, it is considered that the narrow strip sand body is not formed by the deposition of narrow deep channel, but by the superposition of multi-stage distributary channel sand bodies in shallow water delta. This study breaks the original understanding of the area and explains the cause of formation of narrow strip sand body. It is a useful exploration of distributary channel of shallow Delta.

\section{Deposition Environment of Underwater Distributary Channel in Shallow-Water Delta}

\subsection{Characteristics of Paleotopography and Formation Thickness}

In the whole basin, whether it is the delta plain near the source area or the delta front far from the source, the formation thickness does not change much and the slope is generally less than $0.5^{\circ}$ (Figure 1). The formation thickness is stable, which shows that in the deposition period of the lower Minghuazhen Formation in B19-4 Oilfield, the terrain was gentle and the water body was shallow [7].

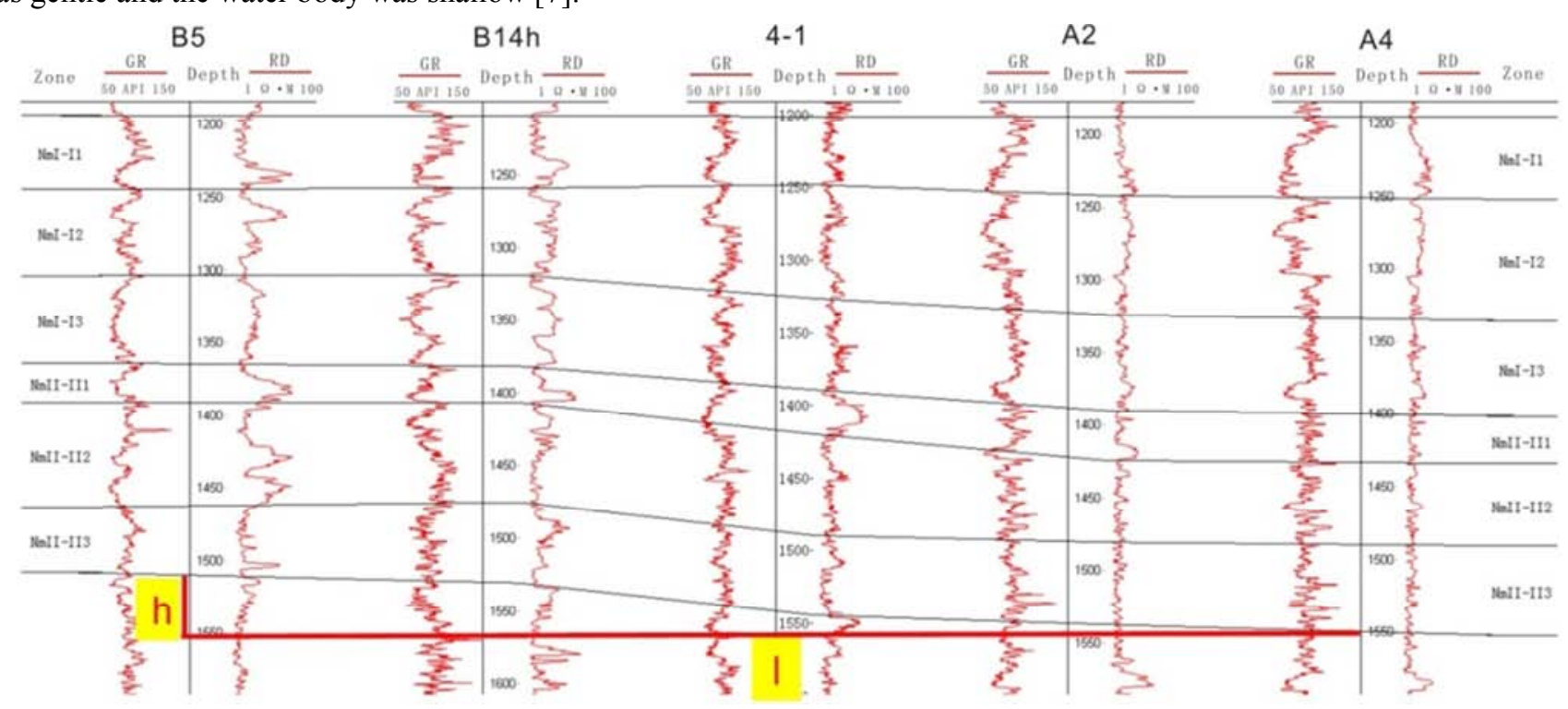

Figure 1. Gradual change of formation thickness of B19-4 Oilfield (gradient $i=h / l \times 100 \%=0.5 \%$ ).

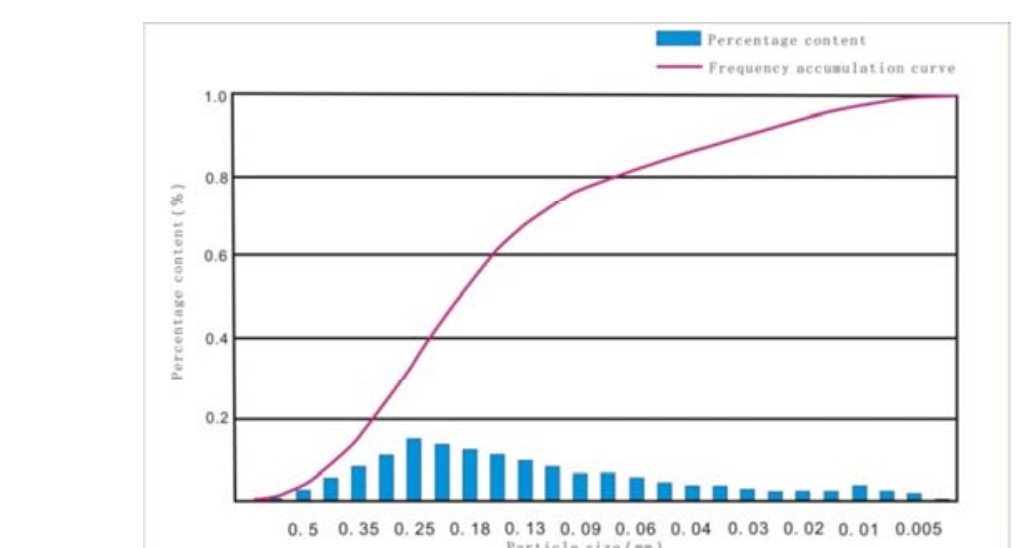

$\begin{array}{llllllllllllll}0.5 & 0.35 & 0.25 & 0.18 & 0.13 & 0.09 & 0.06 & 0.04 & 0.03 & 0.02 & 0.01 & 0.005\end{array}$

Figure 2. Particle size samples distribution of NmIII and NmIV oil sets of B19-4 Oilfield.
The distributary channel of the shallow water delta in the study area is a mixed loading channel, which controls the filling of sediment by riverbed accretion and bank deposition [6]. Different from the characteristics of large water flow and strong carrying capacity of bottom loaded river channel, mixed loaded river channel is characterized by shallow distributary channel, small fluctuation of bottom scouring surface, mostly curved channel, small water flow and weak carrying capacity. The core observation shows that the sediments are mainly a mixture of fine sand, silty sand and mud, and the cumulative curve of particle size frequency also shows that the $80 \%$ cumulative content corresponds to a particle size range of 0.08 to $0.7 \mathrm{~mm}$, most of which are concentrated in the range of 0.13 to $0.4 \mathrm{~mm}$, and well sorted (Figure 2). The overall feature is fine particle deposition far from the source, reflecting that the hydrodynamic force during the deposition period of NmIII and NmIV is not strong, and it is not easy for the river channel to change course, thus forming multi-stage channel superimposed sand body (Figure 3 ). 


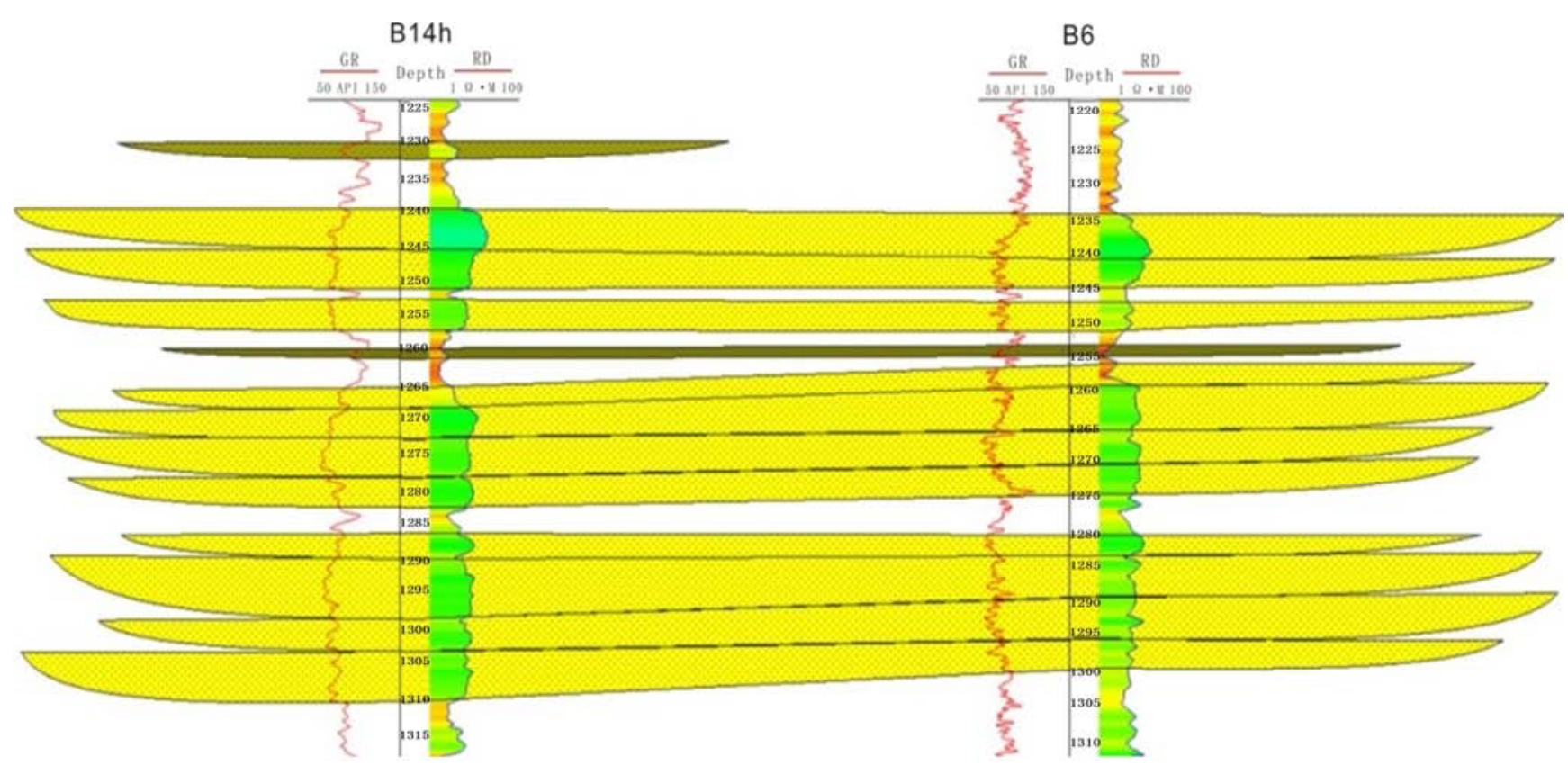

Figure 3. Multiple period channel overlay of NmIII and NmIV oil sets of B19-4 Oilfield.

\subsection{Paleontological Characteristics}

Paleobiological analysis of drilling debris in the target zone of the study area identifies terrestrial herbaceous shrubs, transitional plants, and typical lacustrine micropaleontological fossils. Among them, herbaceous shrubs such as fupingopollenites, ulmipollenites, betulaepollenites and liquidambarpollenites are developed in terrestrial environment, and aquatic magnastriatites and persicarioipollis are generally
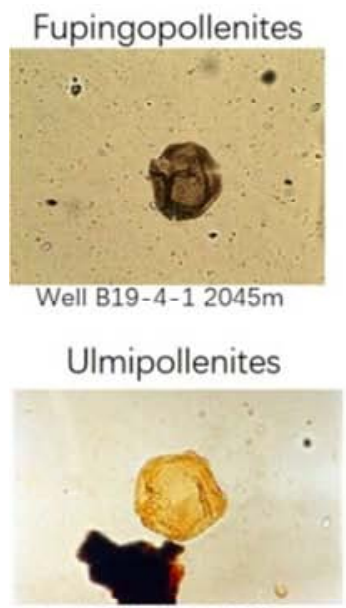

Well B19-4N-1 1795m

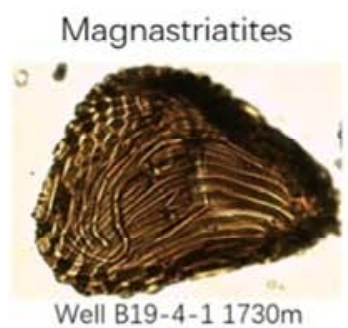

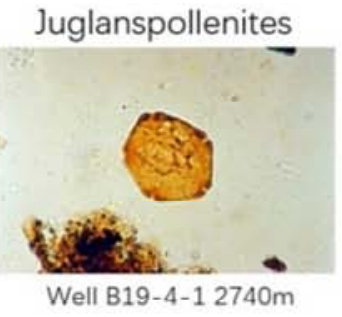
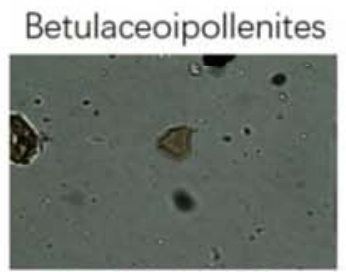

Well B19-4-1 2795m

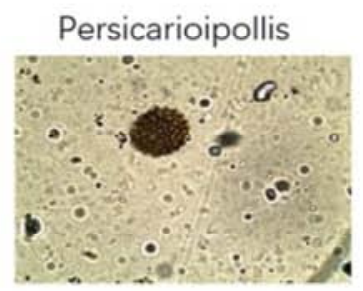

Well B19-4N-1 1795m developed in the land-water transitional environment. Algae combinations such as sporotrapoidites minor, leiosphaeridia, granodiscus and pediastrum are generally developed in shallow freshwater lakes and marsh environments [8-9] (Figure 4). The characteristics of paleontological combinations indicate that the lower Minghuazhen Formation of the study area may have lake delta deposition environment with shallow water body.
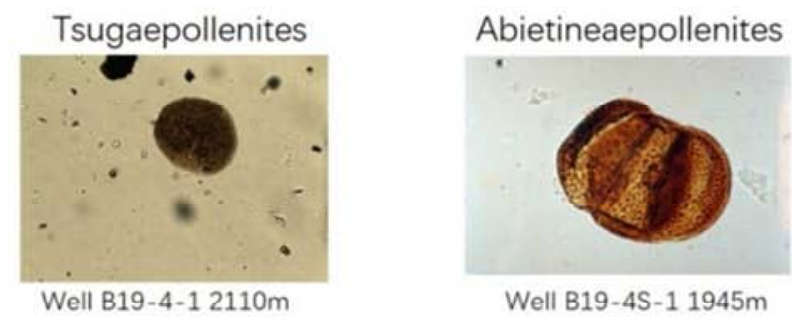

Well B19-4S-1 1945m

Liquidambarpollenites

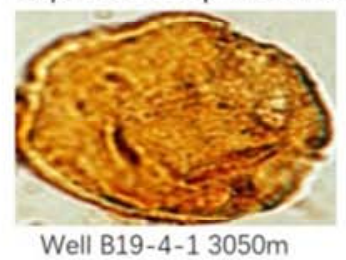

Carya cathayensis

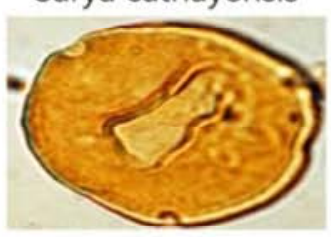

Well B19-4-1 2110m

Sporotrapoidites minor

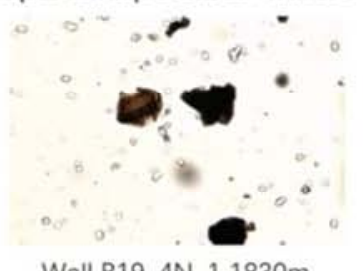

Well B19-4N-1 1830m

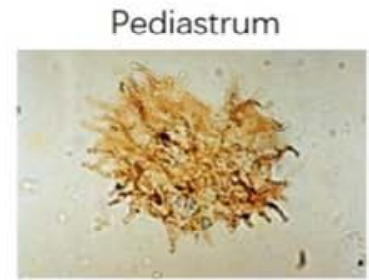

Well B19-4-1 2990m

Figure 4. Paleontology fossil of lower member of Minghuazhen Formation of B19-4 Oilfield. 


\section{Sedimentary Characteristics of Underwater Distributary Channel in Shallow Lacustrine Delta}

\subsection{Sand Body Distribution and Lithologic Features}

The distributary channel sand body in the study area has good continuity along the flow direction and extends far to the lake center, showing narrow strip distribution; the natural dike sedimentary sand body is relatively developed and distributed on both sides of the river; sheet sand is located at the far end of the river and distributed in sheet shape (Figure 5). Logging data shows that red mudstones or brown-red, gray-green mudstones are developed in the lower Minghuazhen Formation, indicating that the water body is shallow and exposed intermittently in the sedimentary period. Drilling core shows that block bedding, parallel bedding, cross bedding, and ripple marks are common in sandstone and horizontal bedding is developed in mudstone (Figure 6). Thin layers of sand and mud are interactively developed, with good differentiation and obvious stratification, reflecting sedimentary characteristics of the shallow lacustrine delta.

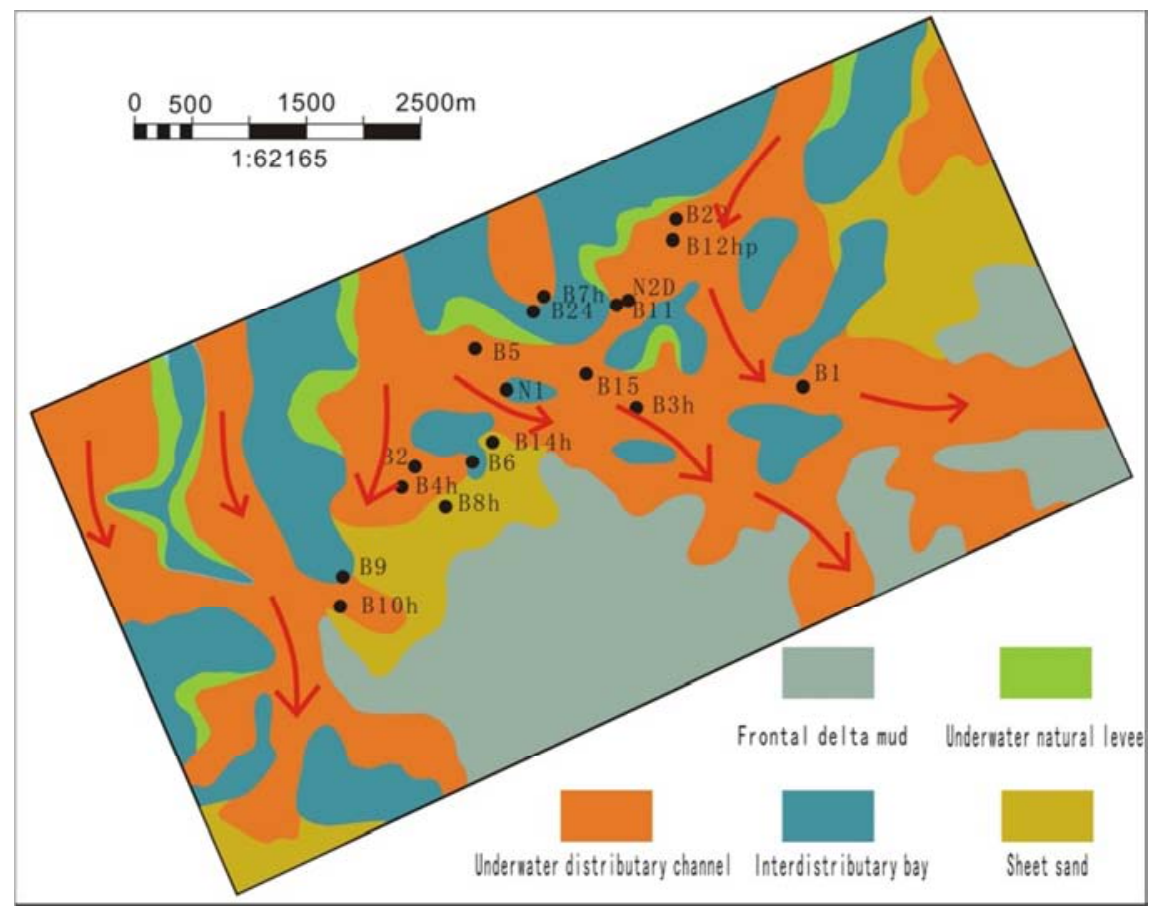

Figure 5. Sedimentary micro-facies graph of lower member of Minghuazhen Formation of B19-4 Oilfield.

B19-4 Oilfield
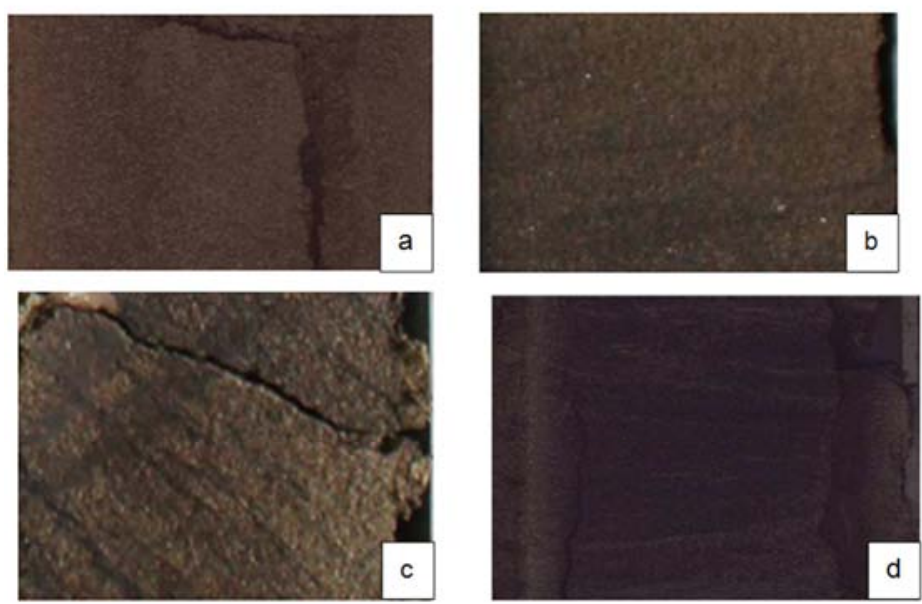

Figure 6. Rock facies of lower member of Minghuazhen Formation of B19-4 Oilfield.

${ }^{\text {a }}$ Massive bedding, well B19-4N-1, 1386.93m; ${ }^{\mathrm{b}}$ Parallel bedding, well B15, 1856.95m; ${ }^{\mathrm{c}}$ Tabular cross bedding, well B15, 1859.68m; ${ }^{\mathrm{d}}$ Trough cross bedding, well B15, $1860.21 \mathrm{~m}$. 


\subsection{Sedimentary Micro-facies Characteristics}

The distributary channel at the front of the shallow lacustrine delta has the characteristics of straight river sedimentation. The microfacies of the (underwater) distributary channel are the most developed; the natural levee is developed; and the crevasse splay is not developed. Log facies analysis also shows that small funnel-shaped or finger-shaped thin reservoirs are mostly developed at the top or bottom of the bell-shaped or box-shaped sandstones of the NmIII and NmIV oil groups in the lower Minghuazhen Formation (Figure 7), indicating that natural levees at the top or bottom of the distributary channel are relatively developed, which makes the river channel highly inherited and difficult to change.

\subsection{Tectonic Evolution and Accommodation Space Changes}

B19-4 oilfield is a complex fault block structure oilfield $[10,11]$, the fault strike is mainly NE direction. During the deposition period of NmIV oil formation in the lower Minghuazhen Formation, the stratum gradually uplifted, forming a local high point near faults F1 and F2. In each period of sedimentation in the lower Minghuazhen Formation, the whole stratum maintains a structural pattern of two convexes and one depression, and the high point in the work area is always located near the north boundary F1 fault (Figure 8), which indicates that the structure of NmIII and NmIV oil formation in the lower Minghuazhen Formation is relatively stable in the sedimentation period [12], providing stable structural factors for the channel not easy to change.

The NmIII and NmIV oil formations in the study area correspond to the base level rising half cycle (Figure 8), which is in the period of stable lake level rising. At this time, the growth rate of accommodation space is relatively large, and the river channel has enough sedimentary space [13]. Because the ratio of the growth rate of accommodation space to the supply rate of sediment (A / $\mathrm{s}$ value) is high, it provides space for the multi-stage stacking of channel sand $[14,15]$.

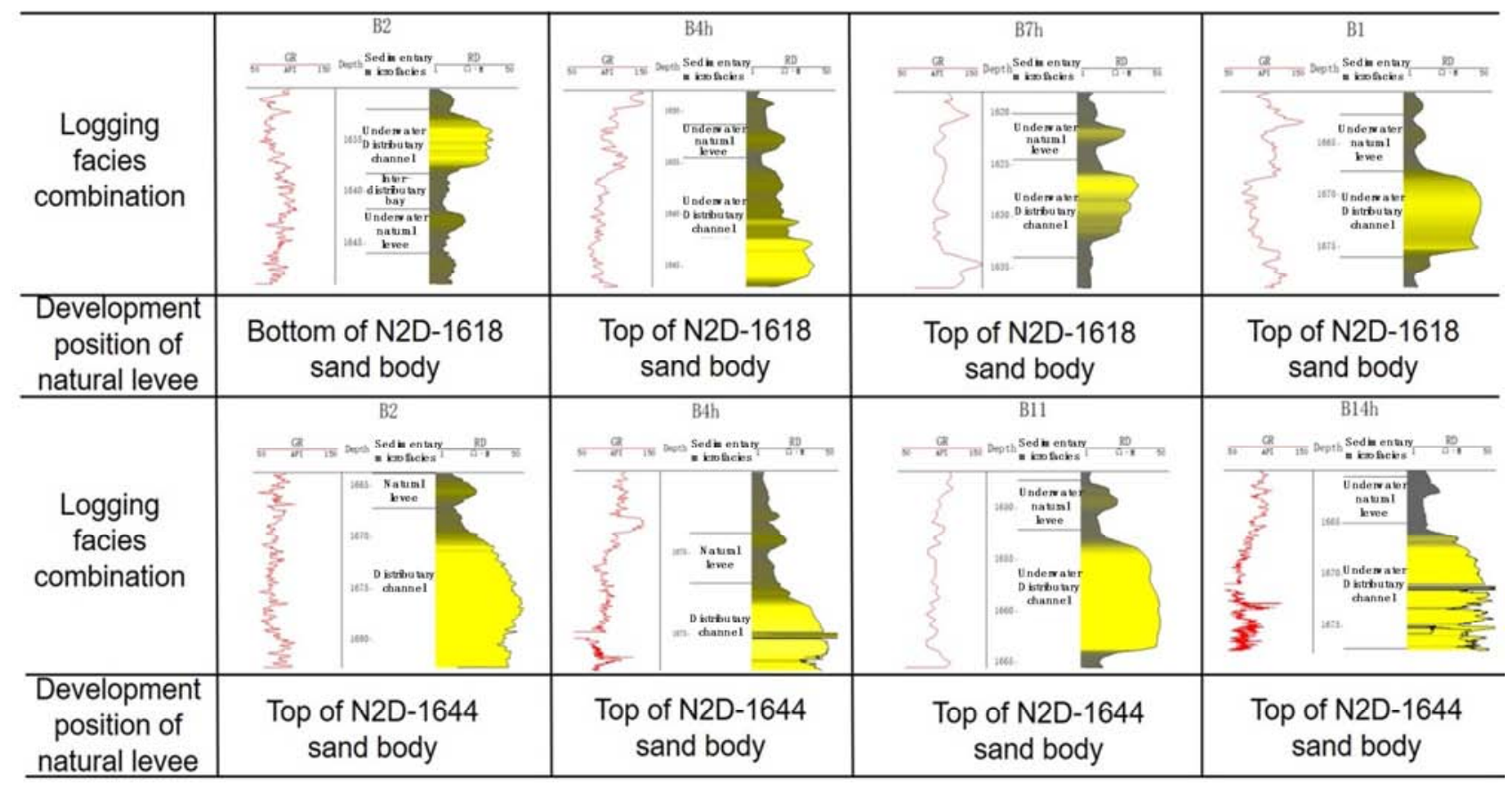

Figure 7. Development condition of natural levee of NmIII and NmIV oil sets of B19-4 Oilfield.

\section{Conclusion}

(1) According to the characteristics of formation thickness, lithology, paleontology and Geophysics, it is confirmed that the NmIII and NmIV oil formations in the lower Minghuazhen Formation of B19-4 Oilfield are shallow water delta deposits, with developed distributary channels, multi-level bifurcations, sheet sands of different degrees, and no estuary bar. The sand body is continuous and extends far underwater, which has the characteristics of narrow, thick, long and curved strip distribution.

(2) Because the distributary channel of the shallow delta is shallow, the hydrodynamic force is not strong, the natural levee is developed, and the structural inheritance is good, the channel is not easy to change. At the same time, because the NmIII and NmIV oil formations are in the period of stable rise of the lake level, and the accommodation space is large, the channel is superimposed in multiple periods.

(3) Based on the sedimentary characteristics analysis of the shallow water delta and the genesis of narrow strip sand bodies in the lower member of Minghuazhen Formation of B19-4 Oilfield, it is considered that the narrow strip sand bodies are not formed by narrow and deep channel, but by the superposition of the multi-stage distributary channel sand bodies of the shallow 
water delta, and the width depth ratio of the single stage channel sand body belongs to the category of normal river.

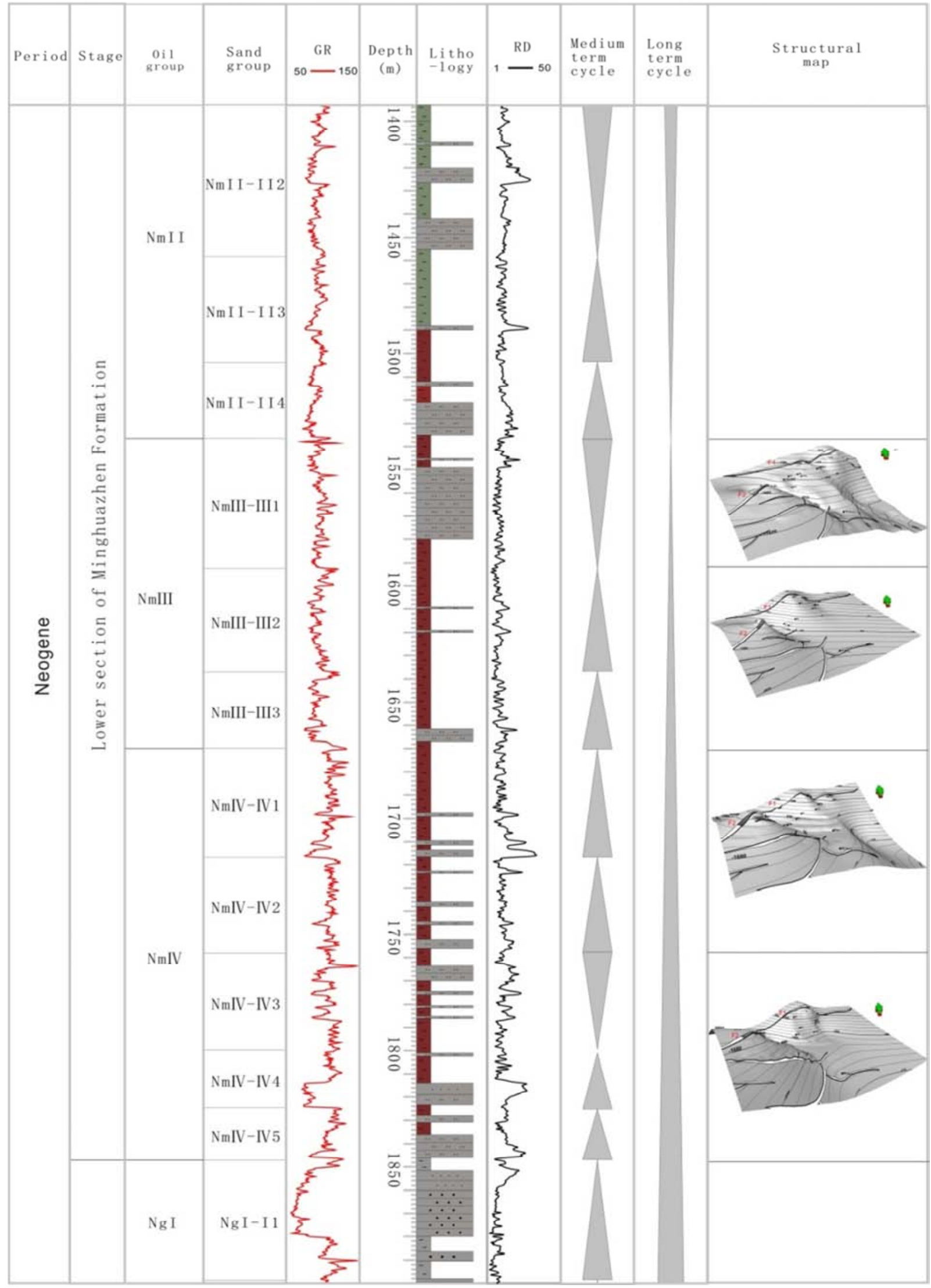

Figure 8. Relationship of base level changes and tectonic evolution of B19-4 Oilfield. 


\section{References}

[1] Wu Shenghe, Xu Zhenhua, Liu Zhao. Depositional architecture of fluvial-dominated shoal water delta [J]. JOURNAL OF PALAEOGEOGRAPHY (Chinese Edition), 2019, 21 (2): 203-210.

[2] Li Chao, Han Xuefang, Hu Yong, et al. Architecture of multiphase narrow-channel sand bodies of shallow lacustrine deltaic facies: a case study on B25-1S oilfield [J]. china petroleum exploration, 2016, 21 (6): 44-49.

[3] Zhu Weilin, Li Jianping, Zhou Xinhuai, et al. Neogene shallow lacustrine deltaic system and large hydrocarbon accumulations in Bohai Bay, China [J]. Acta Sedimentologica Sinica, 2008, 26 (4): 575-582.

[4] Li Chao, Liao Xinwu, et al. Application of seismic sedimentology in B19-4 Oilfield [J]. Fault-block Oil \& Gas Field, 2013, 20 (1): 47-50.

[5] ZHU Xiaomin, LIU Yuan, FANG Qing, et al. Formation and sedimentary model of shallow delta in large-scale lake, Example from Cretaceous Quantou Formation in Sanzhao Sag, Songliao Basin [J]. Earth Science Frontiers, 2012, 19 (1): 89-99.

[6] ZHANG Changmin, YIN Taiju, ZHU Yongjin, et al. Shallow-water deltas and models [J]. Acta Sedimentologica Sinica, 2010, 28 (5): 933-944.

[7] Tan Mingxuan, Zhu Xiaomin, Zhang Zili, Liu Qianghu, Shi Wenlong. Fluvial sequence pattern and its response of geomorphy in depression phase of rift basin: A case study of the Lower Member of Neogene Minghuazhen Formation in Shaleitian Uplift area, Bohai Bay Basin [J]. Journal of Palaeogeography, 2020, 22 (03): 428-439.

[8] Gao Ruiqi, Zhu Zonghao, Zheng Guoguang, et al. Palynology of Petroliferous Basins in China [M]. Beijing: Petroleum Industry Press, 2000: 1-251.
[9] BI Ligang, LI Jianping, et al. Cenozic micropalaeobiotas from the Kenli Structure, Qingdong Depression, Bohai Sea and their bearing on palaeoenvironments [J]. Acta Palaeontologica Sinica, 2009, 48 (2): 155-162.

[10] ZHOU Changsuo, GENG Yanan, LEI Yang, HE Yingming. Experimental research on distribution of in-situ stress of Bozhong 19-6 complex fault block structure [J]. Petrochemical Industry Application, 2020, 39 (01): 84-89.

[11] Wang Guanmin, Xiong Zhouhai, Zhang Jian, et al. Characterization of fault systemand its control on reservoirs in the Bozhong Sag, Bohai Bay Basin [J]. Oil \& Gas Geology, 2017, 38 (01): 62-70.

[12] HOU Guiting, QIAN Xianglin, et al. The Tectonic Evolution of Bohai Basin in Mesozoic and Cenozic Time [J]. Acta Scientiarum Naturalium, Universitatis Pekinensis, 2001, 37 (6): 845-850.

[13] Liu J L, Ji Y L, Yang K M, Zhou Y, Chen X L. 2015. Mechanism of lake shoreline control onshoal water deltaic sandbodies and its significance for petroleum exploration: A case study of Penglaizhen Formation in the middle part of western Sichuan depression. Acta Petrolei Sinica, 36 (9): 1060-1073.

[14] ZHU Xiaomin, ZHAO Dongna, ZENG Hongliu, et al. Sedimentary characteristics and seismic sedimentologic responses of shallow water delta of Qingshankou Formation in Qijia Area, Songliao Basin [J]. Acta Sedimentologica Sinica, 2013, 31 (5): 889-897.

[15] Jia Donghui, Wu Xiaohong, et al. A discussion on features of sedimentary composition of shallow water delta facies: Taking BZ25-1S oilfield as an example [J]. Henan Petroleum, 2005, 19 (2): 4-7. 